\title{
ANALISIS CARBON FOOTPRINT YANG DIHASILKAN DARI AKTIVITAS RUMAH TANGGA DI KELURAHAN LIMBUNGAN BARU KOTA PEKANBARU
}

\author{
Aryo Sasmita ${ }^{1}$, Jecky Asmura ${ }^{2}$, Ivnaini Andesgur ${ }^{3}$ \\ 1,2,3 Program Studi Teknik Lingkungan, Fakultas Teknik, Universitas Riau \\ Email: aryosasmita@gmail.com
}

\begin{abstract}
Abstrak
Tingginya tingkat kepadatan penduduk di Kelurahan Limbungan Baru memiliki potensi sebagai salah satu penyumbang emisi $\mathrm{CO}_{2}$ ke atmosfer. Emisi $\mathrm{CO}_{2}$ dari aktifitas rumah tangga dibagi menjadi emisi $\mathrm{CO}_{2}$ primer dan sekunder. Emisi $\mathrm{CO}_{2}$ primer berasal dari penggunaan bahan bakar di rumah tangga, sedangkan adalah emisi $\mathrm{CO}_{2}$ sekunder yang dihasilkan dari penggunaan alat-alat listrik di rumah tangga. Data primer diperoleh dari survey dengan melibatkan 98 responden dan data sekunder yaitu peta wilayah, data demografi, dan data daya listrik. Variabel penelitian ini yaitu jumlah bahan bakar LPG dan minyak tanah, dan daya listrik yang terpasang di rumah tersebut. Perhitungan emisi $\mathrm{CO}_{2}$ dilakukan dengan menggunakan metode IPCC 2006. Total emisi $\mathrm{CO}_{2}$ dari kegiatan rumah tangga di Kelurahan Limbungan Baru adalah sebesar 2.194,614 ton $\mathrm{CO}_{2}$ /bulan, dimana emisi $\mathrm{CO}_{2}$ primer adalah sebesar 185,535 ton $\mathrm{CO}_{2} /$ bulan dan emisi $\mathrm{CO}_{2}$ sekunder adalah sebesar 2.009,089 ton $\mathrm{CO}_{2} /$ bulan.
\end{abstract}

Kata Kunci: Carbon footprint, Emisi $\mathrm{CO}_{2}$, Rumah Tangga, Energi Listrik, Bahan Bakar Fosil

\section{Abstract}

The high level of density population in Limbungan Baru Sub-District is as one potential contributor of $\mathrm{CO}_{2}$ emissions. The $\mathrm{CO}_{2}$ emissions from the household activities are divided into primary and secondary $\mathrm{CO}_{2}$ emissions. The primary $\mathrm{CO}_{2}$ emissions is resulting from fuel used in households, while the secondary $\mathrm{CO}_{2}$ emissions is resulting from the used of electric household equipment. Primary data were obtain from survey with 98 respondents and secondary data are maps of the area, demographic and the electric power data. The variable in this research are the amount of $L P G$ and kerosene fuels, electrical power that provided for that house.. $\mathrm{CO}_{2}$ emmision were calculated using IPCC method 2006. Total $\mathrm{CO}_{2}$ emissions from household activities in Limbungan Baru baru Sub-District is 2.194,614 tons $\mathrm{CO}_{2} /$ month where primary $\mathrm{CO}_{2}$ emissions amounted to 185,535 tons $\mathrm{CO}_{2} /$ month, and secondary $\mathrm{CO}_{2}$ emissions amounted to 2.009,089 tons $\mathrm{CO}_{2} /$ month.

Keywords: Carbon footprint, $\mathrm{CO}_{2}$ emission, Household, Electricity Energy, Fossil Fuels

\section{PENDAHULUAN}

Pemanasan global dipicu oleh meningkatnya gas-gas rumah kaca (GRK) telah menjadi perhatian masyarakat dunia dalam beberapa dekade terakhir. Dalam konteks gas rumah kaca (GRK) sebagai emisi gas buang yang dilepaskan ke udara ambien, penyumbang emisi terbesar dalam gas rumah kaca adalah emisi karbondioksida. Lebih dari $75 \%$ komposisi gas rumah kaca di atmosfer adalah $\mathrm{CO}_{2}$. Hampir seluruh kegiatan manusia setiap harinya telah berkontribusi terhadap kenaikan emisi gas rumah kaca di atmosfer. Saat ini aktivitas manusia cenderung berasal dari 
bahan bakar fosil seperti minyak bumi, gas alam dan batubara. Kebutuhankebutuhan tersebut semakin bertambah seiring dengan peningkatan jumlah penduduk, jumlah aktivitas, dan gaya hidup masyarakat (Wiratama, 2015).

Gas rumah kaca dari emisi antropogenik berasal dari beberapa sumber contohnya sektor energi yaitu pemanfaatan bahan bakar fosil seperti minyak bumi, batu bara dan gas secara berlebihan dalam berbagai kegiatan merupakan penyebab utama dilepaskannya emisi gas rumah kaca ke atmosfer. Pembangkit listrik, penggunaan alat-alat elektronik seperti $\mathrm{AC}, \mathrm{TV}$, komputer, penggunaan kendaraan bermotor dan kegiatan industri merupakan contoh kegiatan manusia yang meningkatkan emisi GRK di atmosfer (Wulandari, 2013).

Besarnya perhatian pemerintah terhadap emisi gas rumah kaca ini ditunjukkan lewat komitmen Pemerintah Indonesia untuk menurunkan emisi gas rumah kaca sebesar 29\% dengan usaha sendiri dan mencapai $41 \%$ jika mendapat bantuan internasional sampai tahun 2030, hal ini disampaikan Presiden Jokowi pada pidatonya di Paris Perancis, 30 November 2015 dalam The Confrence of Parties (COP) ke-21 pada Konvensi Kerangka Kerja Sidang PBB tentang perubahan Iklim atau United Nations Frameworks Convetion on Climate Change (UNFCCC). Selain itu, Indonesia juga telah memiliki rencana aksi nasional secara menyeluruh untuk mengurangi emisi gas rumah kaca yang tercantum dalam Peraturan Presiden Republik Indonesia Nomor 61 Tahun 2011 tentang Rencana Aksi Nasional Penurunan Emisi Gas Rumah Kaca dan Peraturan Presiden Republik Indonesia Nomor 71 Tahun 2011 tentang Penyelenggaraan Inventarisasi Gas Rumah Kaca Nasional (Sasmita, 2017).

Penyumbang emisi $\mathrm{CO}_{2}$ yaitu sebanyak $15 \%$ berasal dari aktivitas rumah tangga (Wuryandari, 2016). Pemanfaatan energi sektor rumah tangga yaitu terkait dengan kebutuhan tenaga listrik (untuk penerangan, pengkondisian ruangan, peralatan elektronik lainnya) dan energi panas untuk memasak. Kebutuhan energi panas dipenuhi dengan pembakaran BBM misalnya minyak tanah, LPG, gas bumi (untuk beberapa wilayah kota besar) dan kayu bakar (untuk beberapa wilayah pinggiran kota dan pedesaan). Di beberapa daerah yang belum memiliki akses ke tenaga listrik, kebutuhan akan penerangan dipenuhi dengan memanfaatkan lampu minyak tanah (Kementrian Energi dan Sumber Daya Mineral, 2012). Dalam upaya mendukung pemerintah, data yang terkait dengan konsumsi energi sangat diperlukan, terutama dari aktivitas di rumah tangga yang merupakan salah satu sumber utama salah satu emisi gas rumah kaca yaitu gas karbon dioksida $\left(\mathrm{CO}_{2}\right)$.

Berdasarkan data BPS 2017 Kelurahan Limbungan Baru merupakan kelurahan terpadat di Kecamatan Rumbai Pesisir Kota Pekanbaru dengan jumlah penduduk yaitu sebesar 20.611 jiwa, dengan kepadatan penduduknya mencapai $9.862 \mathrm{jiwa} / \mathrm{km}^{2}$. Tingginya jumlah penduduk dengan beragam aktivitas penduduk ini tentunya akan berpengaruh terhadap emisi $\mathrm{CO}_{2}$ yang dihasilkan dari aktivitas rumah tangga, ditambah lagi dengan sedikitnya jumlah pohon dan kawasan hijau yang berfungsi menyerap gas karbon dioksida (Pradiptyas, 2011). Berdasarkan latar belakang tersebut penelitian ini perlu dilaksanakan untuk mengetahui seberapa besar carbon footprint dari aktivitas rumah tangga di Kelurahan Limbungan Baru, karena sampai sekarang masih minim sekali data carbon footprint yang dihasilkan oleh aktivitas di tingkat rumah tangga (Astari, 2012).

Ditetapkan disini bahwa carbon footprint dibagi menjadi 2 yaitu carbon footprint primer dan carbon footprint sekunder. Carbon footprint primer 
merupakan ukuran emisi $\mathrm{CO}_{2}$ yang bersifat langsung. Carbon footprint primer didapat dari hasil pembakaran bahan bakar fosil seperti memasak dan transportasi, sedangkan Carbon footprint sekunder merupakan emisi karbondioksida yang bersifat tidak langsung. Carbon footprint sekunder dihasilkan dari peralatan-peralatan elektronik rumah tangga dimana peralatan elektronik tersebut dapat difungsikan dengan menggunakan daya listrik (Puri, 2010).

Penelitian ini bertujuan untuk menghitung jumlah emisi $\mathrm{CO}_{2}$ dari aktivitas rumah tangga di kelurahan Limbungan Baru Kecamatan Rumbai Pesisir Kota Pekanbaru, dan menganalisa faktor-faktor yang berpengaruh terhadap emisi $\mathrm{CO}_{2}$ dari aktivitas rumah tangga di kelurahan tersebut. Diharapkan dari penelitian ini akan menjadi data dasar untuk menyusun rencana pengurangan emisi dari aktivitas rumah tangga di kelurahan tersebut.

\section{METODE}

$\begin{array}{rrr}\text { Pada } & \text { penelitian ini } & \text { dilakukan } \\ \text { perhitungan } & \text { terhadap } & \text { emisi }\end{array}$ karbondioksida yang dihasilkan dari aktivitas rumah tangga di Kelurahan Limbungan Baru Kecamatan Rumbai Pesisir Kota Pekanbaru, dimana data yang akan dikumpulkan adalah data

$$
n=\frac{\mathrm{N}}{1+\mathrm{N} \propto^{2}} \ldots \ldots . .(\text { Husein, } 2005)
$$

Keterangan:

$\mathrm{n} \quad=$ Jumlah sampel wilayah studi

$\mathrm{N} \quad=$ Jumlah total dari keseluruhan KK yang ada di wilayah studi

$\propto \quad=$ Derajat kesalahan yang digunakan (10\%)

\section{Variabel Penelitian}

1. Emisi $\mathrm{CO}_{2}$ primer yaitu jumlah bahan bakar rumah tangga LPG dan minyak tanah.

2. Emisi $\mathrm{CO}_{2}$ sekunder yaitu dari konsumsi listrik dengan daya listrik rumah yang terbagi menjadi 900 VA, primer yang didapat melalui survei. Data yang didapat dari survei ini berupa jumlah konsumsi listrik, bahan bakar yang digunakan untuk memasak, dan banyak pemakaiannya dalam satu bulan. Selain data primer, data sekunder juga diperlukan dalam penelitian ini yaitu berupa data yang didapat dari pihak yang terkait dan berhubungan dengan penelitian ini. Dari data yang diperoleh tersebut selanjutnya dilakukan perhitungan, analisis, dan pembahasan untuk mencapai tujuan dari penelitian ini.

\section{Populasi Penelitian}

Populasi adalah keseluruhan objek penelitian atau objek yang diteliti. Populasi pada penelitian ini adalah seluruh kepala keluarga (KK) yang terdaftar di wilayah administratif Kelurahan Limbungan Baru Kecamatan Rumbai Pesisir Kota Pekanbaru. Penelitian ini akan menggunakan metode penarikan sampel acak (random sampling) berstrata proporsional terhadap jumlah total kepala keluarga pada wilayah studi yang dibagi berdasarkan daya listrik. Dengan menggunakan metode penarikan sampel acak maka tidak keseluruhan populasi yang akan diuji melainkan hanya sejumlah tertentu yang jumlahnya ditentukan dengan menggunakan persamaan berikut ini: 

dihasilkan dari Aktivitas Rumah Tangga di Kelurahan Limbungan Baru Kota Pekanbaru

lapangan. Sedangkan data sekunder didapatkan dari data-data yang sudah ada terlebih dahulu. Pengumpulan data primer dalam penelitian ini dilakukan dengan pendataan jumlah dan jenis bahan bakar serta jumlah konsumsi listrik yang digunakan dari aktivitas rumah tangga di Kelurahan Limbungan Baru dengan kuisioner dan wawancara. Pengumpulan data sekunder yaitu meliputi data demografi Kelurahan Limbungan Baru Kecamatan Rumbai Pesisir Kota Pekanbaru, peta wilayah Kelurahan Limbungan Baru Kecamatan Rumbai Pesisir Kota Pekanbaru, dan data daya listrik.

1. Emisi $\mathrm{CO}_{2}$ primer

Emisi $\mathrm{CO}_{2}=\mathrm{EF}$ x Fcy x NCV

Keterangan:

Fcy : bahan bakar yang dikonsumsi (Kg/bulan)

$\mathrm{EF} \quad$ : Faktor emisi $\mathrm{CO}_{2}$ bahan bakar (satuan massa/MJ)

NCV : Net Calorific Volume (energy content) per unit massa atau volume bahan bakar.

2. Emisi $\mathrm{CO}_{2}$ sekunder

Emisi $\mathrm{CO}_{2}=\mathrm{EF} x$ Konsumsi listrik (persamaan 2)

Keterangan:

Konsumsi listrik : Listrik yang dikonsumsi (KWh)

EF

: Emisi faktor $\mathrm{CO}_{2}$ konsumsi listrik

3. Emisi $\mathrm{CO}_{2}$ total

Emisi $\mathrm{CO}_{2}$ total $=$ Emisi $\mathrm{CO}_{2}$ primer + Emisi $\mathrm{CO}_{2}$ sekunder $($ IPCC, 2006)

\section{HASIL DAN PEMBAHASAN}

\section{Penyajian Data Primer}

Pengumpulan data primer dalam penelitian ini dilakukan dengan pendataan jumlah dan jenis bahan bakar serta jumlah konsumsi listrik yang digunakan dari aktivitas rumah tangga di Kelurahan Limbungan Baru Kecamatan Rumbai Pesisir Kota Pekanbaru dengan kuisioner dan wawancara.

Data populasi pada penelitian ini didapatkan dari Badan Pusat Statistik Kota Pekanbaru tahun 2017. Data populasi pada penelitian ini adalah seluruh kepala keluarga (KK) yang terdaftar di wilayah administratif
Kelurahan Limbungan Baru Kecamatan Rumbai Pesisir Kota Pekanbaru, jumlah kepala keluarga (KK) pada kelurahan Limbungan Baru ini sendiri adalah sebanyak 4.550 KK. Pada penelitian ini digunakan metode penarikan sampel acak (random sampling) berstrata proporsional terhadap jumlah total kepala keluarga pada wilayah studi. Dengan menggunakan metode penarikan sampel acak maka tidak keseluruhan populasi yang akan diuji melainkan hanya sejumlah tertentu yang jumlahnya ditentukan dengan menggunakan persamaan berikut.

Diketahui :

$\mathrm{N}=4.550 \mathrm{KK}$ 

dihasilkan dari Aktivitas Rumah Tangga di Kelurahan Limbungan Baru Kota Pekanbaru

$\propto=10 \%$

Perhitungan :

$n=\frac{\mathrm{N}}{1+\mathrm{N}^{2}}$

$=\frac{4550}{1+(4550)(0,1)^{2}}=98 \mathrm{KK}$

Jadi jumlah sampel yang akan diteliti pada penelitian ini adalah sebanyak 98 kepala keluarga dibagi berdasarkan daya listrik, data daya listrik sendiri didapat dari data pelanggan Perusahaan Listrik Negara (PLN) Rayon Rumbai. Berikut ini adalah data jumlah sampling kuisioner yag dapat dilihat pada Tabel 1

Tabel 1 Data Jumlah Sampel di Kelurahan Limbungan Baru

\begin{tabular}{ccc}
\hline Daya Listrik & Jumlah KK & Jumlah Sampel \\
\hline 900 VA & 1.300 & 28 \\
1300 VA & 1.671 & 36 \\
2200 VA & 928 & 20 \\
3500 VA & 604 & 13 \\
4400 VA & 47 & 1 \\
\hline Total & $\mathbf{4 . 5 5 0}$ & $\mathbf{9 8}$ \\
\hline
\end{tabular}

Contoh untuk jumlah sampel dengan daya listrik 900 VA adalah sebagai berikut:

Diketahui:

Jumlah KK Pengguna Daya Listrik 900 VA $\quad=1.300 \mathrm{KK}$

Jumlah Total KK

Jumlah Total Sampel

$=4.550 \mathrm{KK}$

$=98$

Perhitungan:

Jumlah Sampe untuk Daya Listrik 900 VA $=\frac{\text { Jumlah } K K \times \text { Jumlah Total Sampel }}{\text { Jumlah Total } K K}$ $=\frac{1.300 \times 98}{1300}$

$=28$ Sampel

Perhitungan Emisi Karbon Dioksida $\left(\mathrm{CO}_{2}\right)$

Emisi $\mathrm{CO}_{2}$ dalam penelitian ini adalah emisi $\mathrm{CO}_{2}$ yang dihasilkan dari kegiatan rumah tangga. Emisi $\mathrm{CO}_{2}$ yang dihasilkan dari kegiatan rumah tangga kemudian digolongkan menjadi dua yaitu emisi $\mathrm{CO}_{2}$ primer dan emisi $\mathrm{CO}_{2}$ sekunder. Emisi $\mathrm{CO}_{2}$ primer adalah emisi yang berasal dari penggunaan bahan bakar rumah tangga sedangkan emisi $\mathrm{CO}_{2}$ sekunder yang dihasilkan dari penggunaan listrik rumah tangga.

\section{Emisi Karbon Dioksida $\left(\mathrm{CO}_{2}\right)$ Primer}

Emisi $\mathrm{CO}_{2}$ primer merupakan emisi yang dihasilkan dari penggunaan bahan bakar di rumah tangga. Bahan bakar untuk rumah tangga yang diteliti adalah LPG dan minyak tanah. Untuk menghitung nilai emisi $\mathrm{CO}_{2}$ yang dihasilkan dari bahan bakar rumah tangga, digunakan dua perhitungan yang berbeda untuk masing-masing jenis bahan bakar yang digunakan. Berikut ini adalah contoh perhitungan berdasarkan sampling kuesioner di satu rumah.

Untuk menghitung emisi $\mathrm{CO}_{2}$ dari bahan bakar LPG dan minyak tanah digunakan rumus perhitungan pada persamaan 1 berdasarkan metode IPCC. Contoh Perhitungan dalam 1 rumah/bulan untuk konsumsi LPG sebesar $12 \mathrm{~kg}$ adalah sebagai berikut:

Diketahui: 
Aryo Sasmita, Jecky Asmura, \& Ivnaini Andesgur : Analisis Carbon Footprint yang dihasilkan dari Aktivitas Rumah Tangga di Kelurahan Limbungan Baru Kota Pekanbaru

$$
\begin{aligned}
& \mathrm{EF} \quad=63,07 \mathrm{~g} \mathrm{CO}_{2} / \mathrm{MJ}(\mathrm{IPCC}, 1996) \\
& \text { Fcy } \quad=12 \mathrm{~kg} \\
& \mathrm{NCV}=48,85 \mathrm{MJ} / \mathrm{kg} \text { (IPCC, 1996) } \\
& \text { Perhitungan: } \\
& \text { Pey }=\mathrm{EF}_{\mathrm{CO} 2} \times \text { Fcy } \times \mathrm{NCV}_{\mathrm{LPG}} \\
& =63,07 \mathrm{~g} \mathrm{CO}_{2} / \mathrm{MJ} \times 12 \mathrm{~kg} \mathrm{x} \\
& 48,85 \mathrm{MJ} / \mathrm{kg} \\
& \begin{array}{lll}
= & 36.973,148 \quad \mathrm{~g}
\end{array}
\end{aligned}
$$

\begin{tabular}{|c|c|c|c|}
\hline \multicolumn{2}{|c|}{ Emisi Primer } & \multirow{2}{*}{$\begin{array}{c}\text { Jumlah } \\
\text { Sampel } \\
1\end{array}$} & \multirow{2}{*}{$\begin{array}{c}\begin{array}{c}\text { Hasil Perhitungan } \\
\text { (ton } \mathrm{CO}_{2} \text { /bulan) }\end{array} \\
0,055\end{array}$} \\
\hline$\overline{L P G}$ & $18 \mathrm{~kg}$ & & \\
\hline LPG & $15 \mathrm{~kg}$ & 14 & 0,644 \\
\hline LPG & $12 \mathrm{~kg}$ & 54 & 1,998 \\
\hline LPG & $6 \mathrm{~kg}$ & 23 & 0,414 \\
\hline LPG & $3 \mathrm{~kg}$ & 1 & 0,009 \\
\hline Minyak Tanah & 20 liter & 4 & 0,204 \\
\hline Minyak Tanah & 10 liter & 1 & 0,026 \\
\hline Total & & 98 & 3,350 \\
\hline
\end{tabular}

$\mathrm{EF} \quad=71,87 \mathrm{~g} \mathrm{CO}_{2} / \mathrm{MJ}$ (IPCC,
1996)

Fcy $=20$ liter $=16 \mathrm{~kg}$

$\mathrm{NCV}=44,75 \mathrm{MJ} / \mathrm{kg}$ (IPCC, 1996)

Perhitungan:

$$
\begin{aligned}
\text { Pey }= & \mathrm{EF}_{\text {kerosene }} \mathrm{x} \text { Fcy } \\
& \mathrm{NCV}_{\text {kerosene }} \mathrm{x} \\
= & 71,87 \mathrm{~g} \mathrm{CO}_{2} / \mathrm{MJ} \times 16 \mathrm{~kg} \mathrm{x} \\
& 44,75 \mathrm{MJ} / \mathrm{kg} \\
= & 51.458,920 \mathrm{CO}_{2} / \text { rumah/bulan } \\
= & 0,051 \text { ton } \mathrm{CO}_{2} / \text { rumah/bulan }
\end{aligned}
$$

Dari contoh perhitungan diatas dapat dilihat bahwa emisi $\mathrm{CO}_{2}$ primer dari penggunaan bahan bakar minyak tanah salah satu rumah adalah sebesar $51.458,920 \mathrm{~g} \quad \mathrm{CO}_{2} /$ rumah/bulan atau 0,051 ton $\mathrm{CO}_{2} /$ rumah/bulan.

Hasil perhitungan emisi $\mathrm{CO}_{2}$ primer sampel yang dibagi berdasarkan jumlah dan jenis bahan bakar di Kelurahan Limbungan Baru dapat dilihat pada Tabel 2 .

Tabel 2 Hasil Perhitungan Emisi $\mathrm{CO}_{2}$ Primer Sampel

Dari tabel 2 di atas dapat dilihat bahwa total emisi $\mathrm{CO}_{2}$ primer sampel di Kelurahan Limbungan Baru adalah sebesar 3,350 ton $\mathrm{CO}_{2} /$ bulan.

\section{Emisi Karbon Dioksida $\left(\mathrm{CO}_{2}\right)$ Sekunder}

Emisi sekunder merupakan emisi yang dihasilkan dari peralatan-peralatan elektronik rumah tangga yang menggunakan daya listrik. Persamaan 2 yang dipakai untuk menghitung besarnya emisi $\mathrm{CO}_{2}$ sekunder yaitu dengan mengalikan faktor emisi sekunder dengan besarnya daya yang dikonsumsi oleh satu rumah tangga setiap bulannya.

Untuk menghitung emisi $\mathrm{CO}_{2}$ sekunder digunakan rumus perhitungan berdasarkan metode IPCC. Berikut ini adalah contoh perhitungan emisi sekunder yang dihasilkan dari 1 rumah/bulan dengan konsumsi daya listrik sebesar $550 \mathrm{KWh}$.

Diketahui:

$\mathrm{EF}=0,000794$ ton $\mathrm{CO}_{2} / \mathrm{KWh}$ (Kementerian Energi dan Sumber Daya 
Aryo Sasmita, Jecky Asmura, \& Ivnaini Andesgur : Analisis Carbon Footprint yang dihasilkan dari Aktivitas Rumah Tangga di Kelurahan Limbungan Baru Kota Pekanbaru

Mineral Direktorat Jenderal

Ketenagalistrikan, 2016)

Konsumsi Listrik $=550 \mathrm{Kwh} / \mathrm{bulan}$

Perhitungan:

Emisi $\mathrm{CO}_{2}=\mathrm{EF} \times$ Konsumsi listrik (KWh)

$=0,000794$ ton $\mathrm{CO}_{2} / \mathrm{KWh} \mathrm{x}$

$550 \mathrm{Kwh}$

$=0,437$ ton

$\mathrm{CO}_{2} /$ rumah/bulan.

Dari contoh perhitungan di atas dapat dilihat bahwa emisi $\mathrm{CO}_{2}$ sekunder dari konsumsi listrik salah satu rumah adalah sebesar 0,437 ton $\mathrm{CO}_{2} /$ rumah/bulan. Dengan cara yang sama juga dilakukan perhitungan emisi dari konsumsi listrik pada seluruh sampel di Kelurahan Limbungan Baru . Dari hasil perhitungan emisi $\mathrm{CO}_{2}$ sekunder (98 sampel)di Kelurahan Limbungan Baru diketahui emisi Sekunder adalah 37,187 ton $\mathrm{CO}_{2} /$ rumah/bulan)

\section{Emisi Karbon Dioksida $\left(\mathrm{CO}_{2}\right)$ Total}

Berdasarkan tabel 2 maka didapatkan hasil perhitungan untuk total emisi $\mathrm{CO}_{2}$ primer sampel untuk Kelurahan Limbungan Baru Kecamatan Rumbai Pesisir Kota Pekanbaru yaitu sebesar 3,350 ton $\mathrm{CO}_{2} /$ bulan.

Untuk mendapatkan total emisi $\mathrm{CO}_{2}$ primer dapat dilakukan dengan cara mengalikan rata-rata emisi $\mathrm{CO}_{2}$ primer sampel dengan jumlah seluruh KK di Kelurahan Limbungan Baru Perhitungannya adalah sebagai berikut:

Diketahui:

Total Emisi $\mathrm{CO}_{2}$ Primer Sampel $=3,350$ ton $\mathrm{CO}_{2} /$ bulan

Jumlah Sampel $=98 \mathrm{KK}$

Perhitungan:

Rata-rata emisi $=\frac{\text { Total Emisi } \mathrm{CO}_{2} \text { Primer Sampel }\left(\text { ton } \mathrm{CO}_{2} / \text { bulan }\right)}{\text { Jumlah Sampel }}$

$$
\begin{aligned}
& =\frac{3,350 \text { ton } \mathrm{CO}_{2} / \text { bulan }}{98 \mathrm{KK}} \\
& =0,034 \text { ton } \mathrm{CO}_{2} / \text { bulan }
\end{aligned}
$$

Total Emisi $\mathrm{CO}_{2}$ primer $=$ Rata-rata emisi $\mathrm{x}$ Jumlah $\mathrm{KK}$

$$
\begin{array}{r}
=0,035 \times 5.301 \\
=181,208 \text { ton } \mathrm{CO}_{2} / \text { bulan }
\end{array}
$$

Jadi jumlah total emisi $\mathrm{CO}_{2}$ Limbungan Baru Kecamatan Rumbai primer pada Kelurahan Limbungan Baru Pesisir Kota Pekanbaru adalah sebesar Kecamatan Rumbai Pesisir Kota 37,187 ton $\mathrm{CO}_{2} /$ bulan. Maka, untuk Pekanbaru adalah sebesar 181,208 ton perhitungan total emisi $\mathrm{CO}_{2}$ sekunder $\mathrm{CO}_{2}$ /bulan.

Sedangkan hasil perhitungan total emisi

$\mathrm{CO}_{2}$ sekunder sampel untuk Kelurahan

Diketahui:

Total Emisi $\mathrm{CO}_{2}$ Sekunder Sampel $=37,187$ ton $\mathrm{CO}_{2} /$ bulan

Jumlah Sampel $=98 \mathrm{KK}$

Perhitungan:

$$
\begin{aligned}
\text { Rata-rata emisi } & =\frac{\text { Total Emisi } \mathrm{CO}_{2} \text { Sekunder Sampel }\left(\text { ton } \mathrm{CO}_{2} / \text { bulan }\right)}{\text { Jumlah Sampel }} \\
& =\frac{37,187 \text { ton } \mathrm{CO}_{2} / \text { bulan }}{98 \mathrm{KK}^{2}} \\
& =0,379 \text { ton } \mathrm{CO}_{2} / \text { bulan }
\end{aligned}
$$


Aryo Sasmita, Jecky Asmura, \& Ivnaini Andesgur : Analisis Carbon Footprint yang dihasilkan dari Aktivitas Rumah Tangga di Kelurahan Limbungan Baru Kota Pekanbaru

Jadi jumlah total emisi $\mathrm{CO}_{2}$ sekunder pada Kelurahan Limbungan Baru Kecamatan Rumbai Pesisir Kota Pekanbaru adalah 2.011,512 ton $\mathrm{CO}_{2} /$ bulan.
Emisi $\mathrm{CO}_{2}$ total didapat dari penjumlahan emisi $\mathrm{CO}_{2}$ primer dan emisi $\mathrm{CO}_{2}$ sekunder yang didapatkan dari hasil perhitungan sebelumnya. Hasil emisi $\mathrm{CO}_{2}$ total dapat dilihat pada Tabel 3.

Tabel 3 Emisi $\mathrm{CO}_{2}$ Total di Kelurahan Limbungan Baru

\begin{tabular}{clc}
\hline No & \multicolumn{1}{c}{ Emisi $\mathbf{C O}_{2}$} & Jumlah emisi (ton $\mathbf{C O}_{2} /$ bulan) \\
\hline 1 & Primer & 181,208 \\
2 & Sekunder & $2.011,512$ \\
& Emisi $\mathbf{C O}_{2}$ Total & $2.192,720$ \\
\hline
\end{tabular}

Berdasarkan tabel 3 jumlah emisi $\mathrm{CO}_{2}$ total di Kelurahan Limbungan Baru adalah sebesar 2.192,720 ton $\mathrm{CO}_{2}$ /bulan, yang dimana jumlah emisi $\mathrm{CO}_{2}$ sekunder lebih besar dibandingkan dengan emisi $\mathrm{CO}_{2}$ primer, maka dapat diartikan disini bahwa penggunaan listrik dalam aktivitas rumah tangga berkontribusi besar dalam menghasilkan emisi karbon dioksida $\left(\mathrm{CO}_{2}\right)$.

\section{Faktor yang mempengaruhi}

Berdasarkan perhitungan emisi $\mathrm{CO}_{2}$ primer, emisi $\mathrm{CO}_{2}$ sekunder, dan emisi $\mathrm{CO}_{2}$ total di atas, dapat dilihat bahwa besarnya emisi $\mathrm{CO}_{2}$ yang dihasilkan dari suatu tempat atau wilayah yang dalam hal ini adalah wilayah permukiman, dipengaruhi oleh beberapa faktor. Faktor-faktor ini bisa berupa faktor sosial ekonomi ataupun gaya hidup seseorang. Untuk itu, pada penelitian ini dilakukan analisis untuk mengindikasikan faktor-faktor yang dapat mempengaruhi nilai emisi $\mathrm{CO}_{2}$. Variabel-variabel yang diduga dapat mempengaruhi nilai emisi $\mathrm{CO}_{2}$ yang Tabel 4 Rata-rata Emisi $\mathrm{CO}_{2}$ Primer Berdasarkan Jumlah Bahan Bakar LPG dan Minyak Tanah di Kelurahan Limbungan Baru

\begin{tabular}{llrccc}
\hline No & Jumlah Bahan Bakar & $\begin{array}{c}\text { Hasil } \\
\text { Perhitungan } \\
\text { (ton CO2/bulan) }\end{array}$ & $\begin{array}{c}\text { Jumlah } \\
\text { Sampel }\end{array}$ & $\begin{array}{c}\text { Rata-rata Emisi CO } \\
\text { primer/rumah/bulan } \\
\text { (ton CO } \mathbf{C O}_{\text {2 }}\end{array}$ \\
\hline $\mathbf{1}$ & LPG & $18 \mathrm{~kg}$ & 0,055 & 1 & 0.055 \\
$\mathbf{2}$ & LPG & $15 \mathrm{~kg}$ & 0,644 & 14 & 0.046 \\
$\mathbf{3}$ & LPG & $12 \mathrm{~kg}$ & 1,998 & 54 & 0.037 \\
$\mathbf{4}$ & LPG & $6 \mathrm{~kg}$ & 0,414 & 23 & 0.018 \\
\hline
\end{tabular}

akan dianalisis pada penelitian ini yaitu jumlah bahan bakar LPG dan minyak tanah, dan daya listrik

\section{Jumlah Bahan Bakar LPG dan Minyak Tanah}

Untuk mengetahui apakah jumlah bahan bakar LPG dan minyak tanah berpengaruh terhadap emisi $\mathrm{CO}_{2}$ primer, maka dilakukan perhitungan terhadap rata-rata emisi $\mathrm{CO}_{2}$ yang dihasilkan oleh masing-masing rumah sampel yang dikelompokkan berdasarkan jumlah bahan bakar LPG dan minyak tanah yang dikonsumsi pada masing-masing rumah sampel. Setelah melakukan pengelompokkan berdasarkan jumlah bahan bakar LPG dan minyak tanah yang dikonsumsi, selanjutnya dilakukan perhitungan total emisi $\mathrm{CO}_{2}$ primer yang dihasilkan masing-masing jumlah bahan konsumsi bahan bakar dan kemudian dihitung rata-rata emisi $\mathrm{CO}_{2}$ primer yang dihasilkan dengan cara membaginya dengan jumlah sampel. Hasil perhitungan rata-rata emisi $\mathrm{CO}_{2}$ primer berdasrkan jumlah bahan bakar dapat dilihat pada tabel di bawah ini. 
Aryo Sasmita, Jecky Asmura, \& Ivnaini Andesgur : Analisis Carbon Footprint yang dihasilkan dari Aktivitas Rumah Tangga di Kelurahan Limbungan Baru Kota Pekanbaru

\begin{tabular}{llcccc}
\hline $\mathbf{5}$ & LPG & $3 \mathrm{~kg}$ & 0,009 & 1 & 0.009 \\
$\mathbf{6}$ & Minyak Tanah & 201 & 0,204 & 4 & 0.051 \\
$\mathbf{7}$ & Minyak Tanah & 101 & 0,026 & 1 & 0.026 \\
\hline \multicolumn{7}{c}{ Total } & & $\mathbf{3 . 3 5 0}$ & $\mathbf{9 8}$ &
\end{tabular}

Berdasarkan tabel 4 dapat dilihat bahwa rata-rata emisi $\mathrm{CO}_{2}$ primer yang dihasilkan berbanding lurus dengan jumlah bahan bakar LPG dan minyak tanah yang dikonsumsi, ini menunjukkan bahwa emisi $\mathrm{CO}_{2}$ primer dengan jumlah bahan bakar LPG dan minyak tanah di rumah tangga sangat berikatan satu sama lain.

\section{Daya Listrik}

Emisi $\mathrm{CO}_{2}$ sekunder yang berasal dari konsumsi listrik rumah tangga erat kaitannya dengan daya listrik yang digunakan oleh rumah tangga tersebut. Besar daya listrik yang terpasang di suatu rumah menyesuaikan akan kebutuhan listrik rumah tersebut. Semakin besar kebutuhan listriknya, maka daya listrik yang terpasang akan semakin besar, dan pada akhirnya emisi $\mathrm{CO}_{2}$ sekunder yang dihasilkan juga semakin besar. Namun, tetap perlu dianalisis bagaimana hubungan antara daya listrik dan emisi $\mathrm{CO}_{2}$ yang dihasilkan, karena suatu rumah dengan daya listrik terpasang lebih besar dari rumah lainnya belum tentu juga mengkonsumsi energi listrik yang lebih banyak. Besaran daya listrik yang digunakan pada penelitian ini yaitu 900 VA, 1300 VA, 2200 VA, 3500 VA dan 4400 VA.

Untuk mengetahui apakah daya listrik berpengaruh terhadap emisi $\mathrm{CO}_{2}$ sekunder, maka dilakukan perhitungan terhadap rata-rata emisi $\mathrm{CO}_{2}$ yang dihasilkan oleh masing-masing rumah sampel yang dikelompokkan berdasarkan besaran daya listrik yang terpasang pada masing-masing rumah sampel. Setelah melakukan pengelompokkan berdasarkan besaran daya listrik yang terpasang, selanjutnya dilakukan perhitungan total emisi $\mathrm{CO}_{2}$ sekunder yang dihasilkan masingmasing besaran daya listrik dan kemudian dihitung rata-rata emisi $\mathrm{CO}_{2}$ sekunder yang dihasilkan dengan membaginya dengan jumlah sampel masing-masing besaran daya listrik. Hasil perhitungan rata-rata emisi $\mathrm{CO}_{2}$ sekunder berdasarkan daya listrik dapat dilihat pada Tabel 5

Tabel 5 Rata-rata Emisi $\mathrm{CO}_{2}$ Sekunder Berdasarkan Daya Listrik di Kelurahan Limbungan Baru

\begin{tabular}{|c|c|c|c|c|}
\hline No & Daya Listrik & $\begin{array}{c}\text { Total Emisi } \mathrm{CO}_{2} \\
\text { Sekunder (ton } \\
\mathrm{CO}_{2} / \text { bulan) }\end{array}$ & $\begin{array}{l}\text { Jumlah } \\
\text { Sampel }\end{array}$ & $\begin{array}{c}\text { Rata-rata Emisi } \mathrm{CO}_{2} \\
\text { sekunder/rumah/bulan } \\
\quad\left(\text { ton } \mathrm{CO}_{2}\right)\end{array}$ \\
\hline 1 & $900 \mathrm{VA}$ & 4,008 & 28 & 0,143 \\
\hline 2 & $1300 \mathrm{VA}$ & 11,482 & 36 & 0,319 \\
\hline 3 & $2200 \mathrm{VA}$ & 9,701 & 20 & 0,485 \\
\hline 4 & $3500 \mathrm{VA}$ & 10,800 & 13 & 0,831 \\
\hline 5 & $4400 \mathrm{VA}$ & 1,196 & 1 & 1,196 \\
\hline & Total & 37,187 & 98 & \\
\hline $\begin{array}{l}\text { dapat } \\
\text { antara } \\
\text { dihasi }\end{array}$ & $\begin{array}{l}\text { Berdasarkan } \\
\text { dilihat bahwa } \\
\text { rata-rata nila } \\
\text { lkan suatu ru }\end{array}$ & $\begin{array}{l}\text { a pada tabel } 5 \\
\text { rdapat hubungan } \\
\text { emisi } \mathrm{CO}_{2} \text { yang } \\
\text { h dengan daya }\end{array}$ & \multicolumn{2}{|c|}{$\begin{array}{l}\text { listrik yang terpasang di rumah tersebut. } \\
\text { Rumah dengan daya listrik terpasang } \\
\text { sebesar } 4400 \mathrm{VA} \text { menghasilkan rata-rata } \\
\text { emisi } \mathrm{CO}_{2} \text { yang lebih besar dari daya }\end{array}$} \\
\hline
\end{tabular}


Aryo Sasmita, Jecky Asmura, \& Ivnaini Andesgur : Analisis Carbon Footprint yang dihasilkan dari Aktivitas Rumah Tangga di Kelurahan Limbungan Baru Kota Pekanbaru

listrik 3500 VA, 2200 VA, 1300 VA, dan $900 \mathrm{VA}$.

\section{KESIMPULAN}

Dari penelitian ini dapat disimpulkan bahwa Jumlah emisi $\mathrm{CO}_{2}$ yang dihasilkan oleh Kelurahan Limbungan Baru Kecamatan Rumbai Pesisir Kota Pekanbaru adalah sebesar 181,208 ton $\mathrm{CO}_{2} /$ bulan untuk emisi $\mathrm{CO}_{2}$ primer, 2.011,512 ton $\mathrm{CO}_{2} /$ bulan untuk emisi $\mathrm{CO}_{2}$ sekunder, dan 2.192,720 ton $\mathrm{CO}_{2} /$ bulan untuk emisi $\mathrm{CO}_{2}$ total.

\section{UCAPAN TERIMAKASIH}

Penulis mengucapkan terimakasih kepada semua pihak yang telah berkontribusi dalam penyelesaian tulisan ini.

\section{DAFTAR PUSTAKA}

Astari, R. G. 2012. Studi Jejak Karbon dari Aktivitas Permukiman di Kecamatan Pademangan Kotamadya Jakarta Utara.Skripsi. Universitas Indonesia.

Badan PusatStatistik Kota Pekanbaru. 2017. Kecamatan Rumbai Pesisir dalam Angka 2017.

Husein, U. 2005. Teknik Sampling. Jakarta: PT. Gramedia Pustaka Utama.

IPCC. 2006. Energy Guidelines for National Greenhouse Gas Inventories, Vol. 2. Switzerland: Intergovernmental Panel on Climate Change

IPCC. 1996. The emission factors for natural gas are from IPCC Tier 1 default emission factors

Kementerian Energi dan Sumber Daya Mineral Direktorat Jenderal Ketenagalistrikan. 2016. Faktor Emisi Gas Rumah Kaca Sistem Interkoneksi Tahun 2014.

Kementerian Energi dan Sumber Daya Mineral. 2012. www.esdm.go.id/departemenenergi-dan-sumber-daya-mineral.html. Diakses 07 September 2017

Pradiptyas, D. 2011. Analisis Kecukupan Ruang Terbuka Hijau Sebagai Penyerap Emisi $\mathrm{CO}_{2}$ di Perkotaan Menggunakan Program STELLA (Studi Kasus: Surabaya Utara dan Timur). Skripsi. Institut Teknologi Sepuluh Nopember Surabaya.

Puri, R. A.2011. Kajian Emisi CO2 berdasarkan Tapak Karbon Sekunder daro kegiatan Non Akademik di ITS Surabaya. T.Lingkungan FTSP-ITS

Sasmita, Aryo., and Reza, Muhammad. 2017. Prediction of Carbondiocide Emissions from Crude Palm Oil Industry case study: PT.X in Kampar Regency of Riau Province. Proceeding of International Conference On Oleo and Petrochemical Engineering (ICOOPChE) 2017

Wiratama, I. G. 2015. Jejak Karbon Konsumsi LPG dan Listrik pada Rumah Tangga di Kota Denpasar Bali.Tesis Program Pascasarjana, Universitas Udayana.

Wulandari, M. T. 2013. Kajian Emisi $\mathrm{CO}_{2}$ Berdasarkan Penggunaan Energi RumahTangga Sebagai Penyebab Pemanasan Global(Studi Kasus Perumahan Sebantengan, Gedang Asri, Susukan RW 07 Kab. Semarang. Prosiding Seminar Nasional Pengelolaan Sumberdaya Alam dan Lingkungan 2013, Universitas Dipenogoro, Semarang, ISBN 978-602-17001-1-2

Wuryandari, G. 2016. Politik Luar Negeri Indonesia dan Isu Lingkungan Hidup. Jakarta: Lipi Press Jakarta 2013 No. ISBN. 978-979-799-722-9 